AL IBTIDA: JURNAL PENDIDIKAN GURU MI (2017) Vol 4 (1): 61-74

DOI: http://dx.doi.org/10.24235/al.ibtida.snj.v4i1.1463

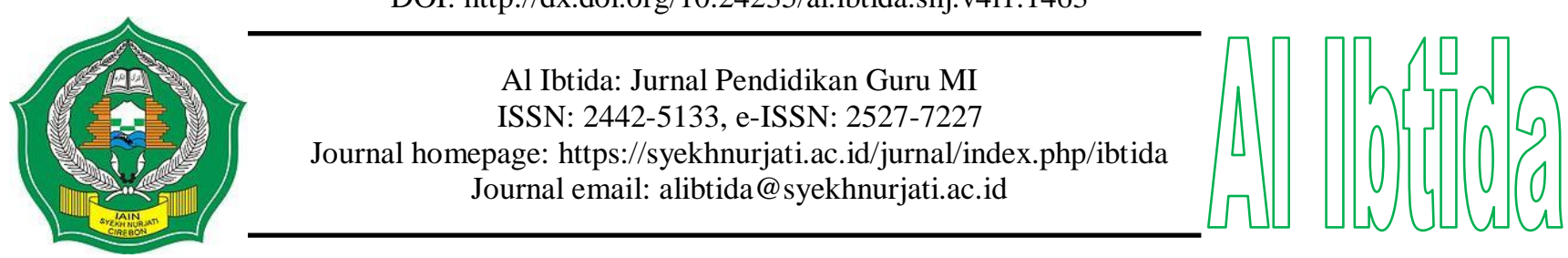

\title{
Pengembangan Lembar Kerja Pembelajaran IPA Berbasis Al Quran untuk Siswa MI
}

\author{
Pipih Nurhayati* \\ * Program Studi Pendidikan Guru Madrasah Ibtidaiyah, Jurusan Tarbiyah, STAI Siliwangi Bandung \\ Email: pipihnurhayati2@gmail.com
}

Received 01 April 2017; Received in revised form 04 May 2017; Accepted 15 May 2017 Published online 19 June 2017

\begin{abstract}
Abstrak
Penelitian ini bertujuan untuk memberikan referensi pengembangan lembar kerja pembelajaran berbasis Al Quran. Metode yang digunakan adalah Research and Development $(R n D)$ dengan implementasi terbatas. Subjek penelitian sebanyak 33 orang siswa SD/MI di Kota Cimahi yang ditentukan secara purposive. Data penelitian berasal dari observasi, judgment expert, angket dan wawancara. Tema IPA yang digunakan adalah Tema tumbuhan yang terbagi menjadi beberapa sub tema yaitu: klasifikasi tumbuhan, pertumbuhan dan perkembangbiakan tumbuhan. Lembar kerja pembelajaran dinilai dari beberapa aspek, yaitu aspek efektifitas praktikum, pedagogi, konten, teknis, dan estetika. Hasil yang diperoleh menunjukan bahwa lembar kerja memiliki nilai efektifitas praktikum yang sangat baik $(93,3 \%)$. Aspek teknis yang kuat $(81,25 \%)$, serta aspek pedagogi, konten dan estetik yang sangat kuat (87,5\%). Setelah mengikuti pembelajaran siswa memberikan respon positif (93\%) terhadap penerapan lembar kerja pembelajaran IPA yang berbasis Al Quran.
\end{abstract}

Kata kunci: lembar kerja, berbasis Al Quran, $M I$

\begin{abstract}
This research aims to provide a reference to developing science worksheet based on Quran. This study using the Research and Development (RnD) method with limited implementation. Subject of this study were 33 students SD / MI in Cimahi who determined purposively. The research data came from observations, expert judgment, questionnaires and interviews. Plant is science theme which used which is divided into several sub-themes: the classification of plants, growth and reproduction of plants. Worksheets learning assessed from several aspects, the effectiveness of lab work, pedagogy, content, technical, and aesthetic. The results obtained show that the worksheet has the practical effectiveness value was excellent (93.3\%). Strong technical aspects (81.25\%), as well as aspects of pedagogy, content and aesthetic is very strong $(87.5 \%)$. After following the learning, students gave positive responses (93\%) of the science worksheet based Quran.
\end{abstract}

Keyword: worksheet, based Quran, MI 


\section{PENDAHULUAN}

Pendidikan pada dasarnya merupakan proses pengembangan potensi siswa melalui pembelajaran yang dilakukan dengan cara mengajarkan berbagai pengetahuan, keterampilan, dan penanaman sikap-sikap yang dibutuhkan oleh siswa. Pada pendidikan formal, siswa dikatakan belajar ketika terdapat perubahan yang bersifat positif pada diri siswa sehingga pada tahap akhir akan diperoleh pengetahuan, keterampilan, dan sikap-sikap baru.

Ilmu pengetahuan alam (IPA) merupakan ilmu yang mempelajari gejala-gejala alam, peristiwa atau fenomena alam serta berusaha untuk mengungkap segala rahasia dan hukum semesta secara ilmiah. Al-Quran memiliki lebih dari 750 ayat tentang fenomena alam. Ayat mengenai gejala alam ini mengajak manusia berpikir dan lebih mendekatkan diri kepada Sang Pencipta Alam. Fenomena alam yang tertulis dalam Al-Quran antara lain dalam bidang biologi, seperti kejadian alam semesta, pembentukan manusia dalam rahim, hingga anatomi tubuh manusia. Menurut Murtono (2005), sains berkaitan dengan cara mencari tahu tentang alam secara sistemis dan dengan kaidah-kaidah tertentu. Sains bukan hanya kumpuIan ilmu pengetahuan yang berupa kata-kata, konsep-konsep dan prinsip-prinsip, tetapi juga bagaimana menemukannya. Pendidikan sains lebih ditekankan pada rasa ingin tahu, dan dengan rasa ini akan menimbulkan semangat untuk berbuat sesuatu sehingga memperoleh pemahaman yang lebih mendalam daripada hanya sekedar tahu saja tentang sifat alam.

Dalam Al-Qur'an telah dijelaskan tentang keharusan untuk mengamati fenomena alam ini sebagai pengembangan rasa ingin tahu,seperti dalam Surat Yunus ayat 101 yang berbunyi:

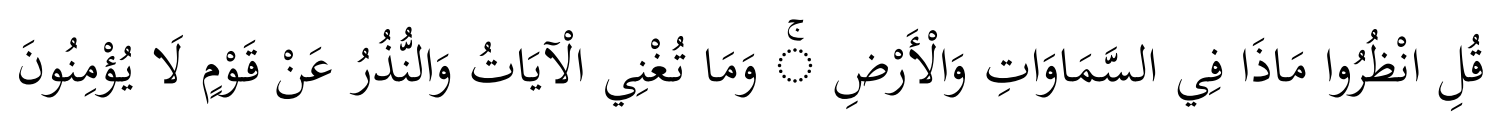

Artinya: Katakanlah:"Perhatikanlah apa yang ada di langit dan dibumi!" Tidaklah bermanfaat tanda-tanda kekuasaan Allah dan rasul-rasul yang memberi peringatan bagi orangorang yang tidak beriman" (Q.S.Yunus:101)

Studi pendahuluan dilakukan dengan memberikan kuisioner tentang pembelajaran sains kepada siswa MI/SD. Sebanyak 45\% siswa lebih menyukai pembelajaran Sains melalui praktikum. Menurut siswa, melalui pembelajaran praktikum siswa lebih memahami materi yang diberikan. Pembelajaran praktikum memiliki banyak keunggulan, antara lain menurut Millar (2004) menyatakan bahwa pembelajaran sains melalui praktikum dapat membantu siswa mengaitkan antara dua domain pengetahuan, yaitu domain objek nyata yang dapat diamati (observable) dan domain pengetahuan pikiran. Selain itu Rustaman (2007) menyatakan bahwa ketika melaksanakan kerja laboratorium siswa menemukan fakta- fakta dan fenomena melalui observasi, sehingga terbentuk suatu konsep untuk memantapkan pengetahuan sebelumnya dan 
atau membentuk pengetahuan yang baru. Dengan demikian dalam kegiatan laboratorium siswa menghubungkan hasil pengamatannya dengan pengetahuan atau teori yang dimilikinya.

Tumbuhan merupakan materi yang memiliki cakupan besar dalam kurikulum sains MI/SD. Dalam Kurikulum materi Tumbuhan dipelajari dari jenjang kelas IV, V, dan VI. Pada kelas IV siswa belajar mengenai hubungan antara struktur bagian tumbuhan dengan fungsinya makhluk hidup. Pada kelas V siswa mempelajari cara tumbuhan hijau membuat makanan. Pada kelas VI siswa mempelajari hubungan antara ciri-ciri makhluk hidup dengan lingkungan tempat hidupnya. Tema tumbuhan ialah konsep yang dekat dengan keseharian siswa dan bersifat konkret sesuai untuk dikembangakan sebagai tema pedoman praktikum bagi siswa MI/SD yang berusia 7-12 tahun.

Pedoman praktikum berperan dalam membimbing siswa melakukan praktikum dalam proses pembelajaran. Sebagai buku bacaan, tidak semua pedoman dapat mengakibatkan siswa giat belajar. Buku yang tidak sesuai dengan psikologis belajar akan menyebabkan sikap anak enggan belajar. Berikut beberapa pertimbangan dalam menentukan buku sains bagi siswa menurut Winataputra (1993: 137), yaitu: 1) memiliki kesesuaian dengan pengalaman siswa; 2)memiliki gaya penulisan yang menarik; 3) memiliki bahasa dan susunan sesuai tingkat perkembangan siswa; 4) memiliki gambar yang menjelaskan suatu teks; 5) ukuran buku sesuai dengan usia pembaca; 6) penuh dengan kegiatan dan pecobaan.

Berdasarkan kriteria penulisan pedoman sains di atas, kriteria tersebut dapat digunakan dalam mengembangan Pedoman Praktikum Siswa. Jika dilakukan klasifikasi kriteria, dari enam kriteria tersebut dapat dibagi menjadi aspek pedagogi, konten, teknis, dan estetik dari suatu buku bacaan. Pengembangan Pedoman Praktikum Siswa tidak lepas dari prinsip pembelajaran IPA melalui pendekatan inkuiri. Langkah pembelajaran melalui praktikum inkuiri secara umum menurut Sanjaya (2009: 201), mencakup:

1) Judul Praktikum, dibuat singkat, jelas menggambarkan praktikum yang akan dilakukan oleh siswa.

2) Fenomena, merupakan gambaran dari suatu situasi atau permasalahan dan disarankan situasi atau permasalahan tersebut terjadi dalam kehidupan sehari-hari. Hal ini bertujuan agar siswa lebih mudah menelaah permasalahan yang dihadirkan dalam kegiatan praktikum.

3) Arahan Dalam Merumuskan Masalah, pada tahap merumuskan masalah, siswa diminta merumuskan pertanyaan berdasarkan fenomena yang telah diamati atau siswa.

4) Arahan Dalam Merumuskan Hipotesis, berisi arahan membuat dugaan sementara berdasarkan infomasi dan pertanyaan yang telah dibuat sebelumnya. 
5) Arahan Dalam Mengumpulkan Data, arahan dalam mengumpulkan data dimulai dari arahan mendesain percobaan dan menyajikan data.

6) Arahan Menguji Hipotesis, siswa diminta memeriksa kesesuaian antara hipotesis awal yang telah dibuat dengan hasil percobaan yang telah dilakukan.

7) Arahan Membuat Kesimpulan, siswa diminta untuk menuliskan kesimpulan hasil percobaannya

Namun, desain pembelajaran yang ada di sekolah memiliki kelemahan secara prosedural (Supriato, 2013) memuat komponen langkah-langkah pembelajaran.Selain itu belum ditemukan pembelajaran sains yang berbasis ayat-ayat Al Quran. Oleh karena itu, penelitian ini bertujuan yang untuk mengembangkan lembar kerja siswa berbasis ayat-ayat Al-Quran pada tema tumbuhan.

\section{METODE PENELITIAN}

Penelitian ini bertujuan untuk memperoleh produk berupa lembar kerja praktikum sains berbasis ayat-ayat Al Quran pada tema tumbuhan untuk siswa MI/SD. Oleh karena itu metode yang digunakan adalah Reserch and Development atau RnD (Borg and Gall, 2003) yang diujicoba secara terbatas. Secara umum penelitian ini dilakukan dalam dua tahapan, yaitu:

1. Studi Pendahuluan

Tahap pertama studi pendahuluan merupakan tahap awal atau persiapan untuk pengembangan. Tahapan tersebut terdiri dari tiga langkah, yaitu:

a. Studi literatur merupakan kajian untuk mempelajari konsep-konsep terhadap teori-teori yang berkenaan dengan produk atau model yang akan dikembangkan.

b. Studi lapangan dilakukan untuk mengumpulkan data berkenaan dengan perencanaan dan implementasi produk di sekolah.

c. Deskripsi hasil studi literatur dan studi lapangan untuk menganalisis dan mendapatkan arah produk yang dikembangkan.

2. Pengembangan Model

Setelah dilakukan kegiatan studi pendahuluan, kegiatan dilanjutkan dengan tahap kedua yaitu tahap pengembangan model. Dalam tahap ini terdapat tahap pengembangan desain model, penyusunan instrumen penelitian, dan uji coba terbatas. 
Bagan 1.Metode Penelitian

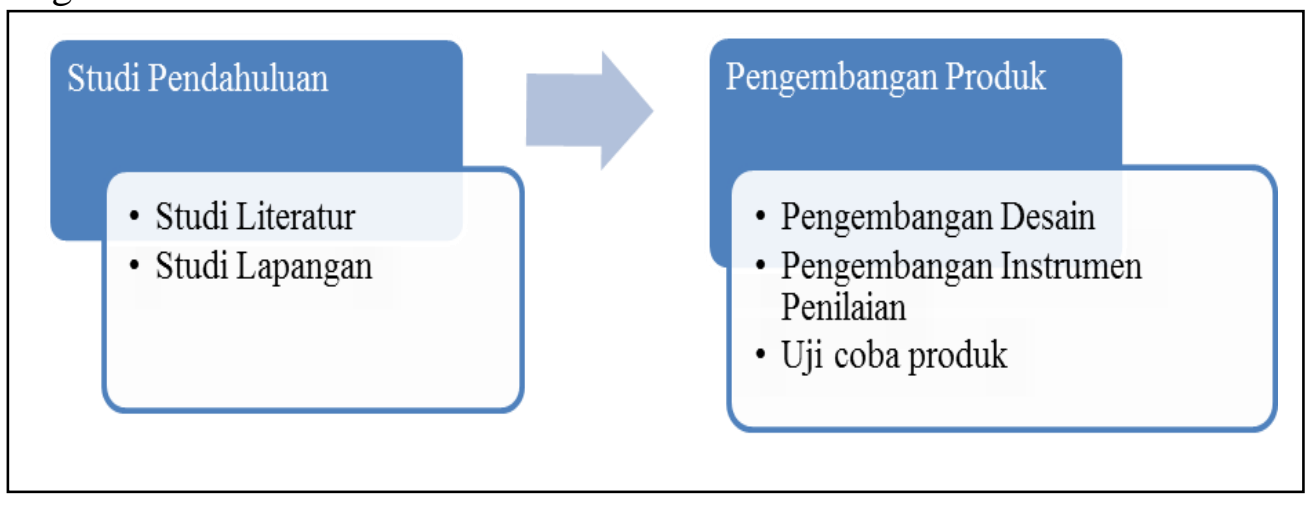

\section{HASIL PENELITIAN DAN PEMBAHASAN}

Pada bahasan ini akan diuraikan hasil temuan-temuan penelitian beserta pembahasannya. Temuan-temuan ini akan disajikan dalam bentuk tabel, bertujuan untuk memudahkan dalam memahami data yang diperoleh. Temuan-temuan penelitian tersebut meliputi: (a) kebutuhan pedoman praktikum sains berbasis ayat Al Quran dalam menunjang pembelajaran di MI/SD; (b) pengembangan Pedoman Praktikum Sains berbasis ayat Al Quran, seri Tumbuhan.

\section{A. Kebutuhan Pedoman Praktikum Sains Berbasis Ayat-ayat Al Quran dalam Menunjang Pembelajaran di MI/SD}

Untuk memperoleh data kebutuhan pedoman praktikum sains dilakukan melalui observasi yang dilakukan di lingkungan sekolah. Analisis dilakukan pada ketersediaan berbanding kebutuhan pedoman praktikum berdasarkan topik sesuai kompetensi dasar. Hasil observasi disajikan pada tabel 1 berikut.

Tabel 1. Analisis Keberadaan Pedoman Praktikum dalam Menunjang Praktikum IPA Tema Tumbuhan di Sekolah

\begin{tabular}{|c|c|c|c|c|}
\hline \multirow{2}{*}{\multicolumn{2}{|c|}{$\begin{array}{l}\text { N Standar Kompetensi/Kompetensi Dasar } \\
\text { o }\end{array}$}} & \multicolumn{2}{|c|}{ Pedoman Praktikum } & \multirow[t]{2}{*}{ Keterangan } \\
\hline & & Ada & Tidak Ada & \\
\hline \multicolumn{5}{|c|}{ Kelas IV/ Semester 1} \\
\hline \multirow{2}{*}{\multicolumn{2}{|c|}{$\begin{array}{l}\text { 1. } \text { Makhluk Hidup dan Proses Kehidupan } \\
\text { a. Memahami hubungan antara struktur organ tubuh manusia } \\
\text { dengan fungsinya, serta pemeliharaannya }\end{array}$}} & \multirow[t]{2}{*}{$\sqrt{ }$} & \multirow[t]{2}{*}{-} & \multirow{2}{*}{$\begin{array}{l}\text { tidak berbasis Ayat-ayat Al } \\
\text { Quran }\end{array}$} \\
\hline & & & & \\
\hline & $\begin{array}{l}\text { b. Memahami hubungan antara struktur bagian tumbuhan } \\
\text { dengan fungsinya }\end{array}$ & $\sqrt{ }$ & - & $\begin{array}{l}\text { tidak berbasis Ayat-ayat } \mathrm{Al} \\
\text { Quran }\end{array}$ \\
\hline & $\begin{array}{l}\text { Memahami hubungan antara struktur bagian tumbuhan } \\
\text { dengan fungsinya }\end{array}$ & $\sqrt{ }$ & - & $\begin{array}{l}\text { tidak berbasis Ayat-ayat } \mathrm{Al} \\
\text { Quran }\end{array}$ \\
\hline & d. Menggolongkan hewan, berdasarkan jenis makanannya & - & $\sqrt{ }$ & \\
\hline & e. Memahami daur hidup beragam jenis makhluk hidup & - & $\sqrt{ }$ & \\
\hline & $\begin{array}{l}\text { Memahami hubungan sesama makhluk hidup dan antara } \\
\text { makhluk hidup dengan lingkungannya }\end{array}$ & - & $\sqrt{ }$ & \\
\hline
\end{tabular}




\begin{tabular}{|c|c|c|c|}
\hline \multirow{2}{*}{$\begin{array}{l}\text { N Standar Kompetensi/Kompetensi Dasar } \\
\text { o }\end{array}$} & \multicolumn{2}{|c|}{ Pedoman Praktikum } & \multirow[t]{2}{*}{ Keterangan } \\
\hline & Ada & Tidak Ada & \\
\hline $\begin{array}{l}\text { 2. } \begin{array}{l}\text { Benda dan Sifatnya } \\
\text { a. Memahami beragam sifat dan perubahan wujud benda serta } \\
\text { berbagai cara penggunaan benda berdasarkan sifatnya }\end{array}\end{array}$ & $\sqrt{ }$ & - & $\begin{array}{l}\text { tidak berbasis Ayat-ayat } \mathrm{Al} \\
\text { Quran }\end{array}$ \\
\hline
\end{tabular}

\section{Kelas IV Semester II}

1 Energi dan Perubahannya

- a. Memahami gaya dapat mengubah gerak dan/atau bentuk suatu benda

b. Memahami berbagai bentuk energi dan cara $\sqrt{ }$ penggunaannya dalam kehidupan sehari-hari

tidak berbasis Ayat-ayat Al Quran

\section{Bumi dan Alam Semesta}

a. Memahami perubahan kenampakan permukaan bumi dan benda langit

b. Memahami perubahan lingkungan fisik dan pengaruhnya terhadap daratan

c. Memahami hubungan antara sumber daya alam dengan lingkungan, teknologi, dan masyarakat

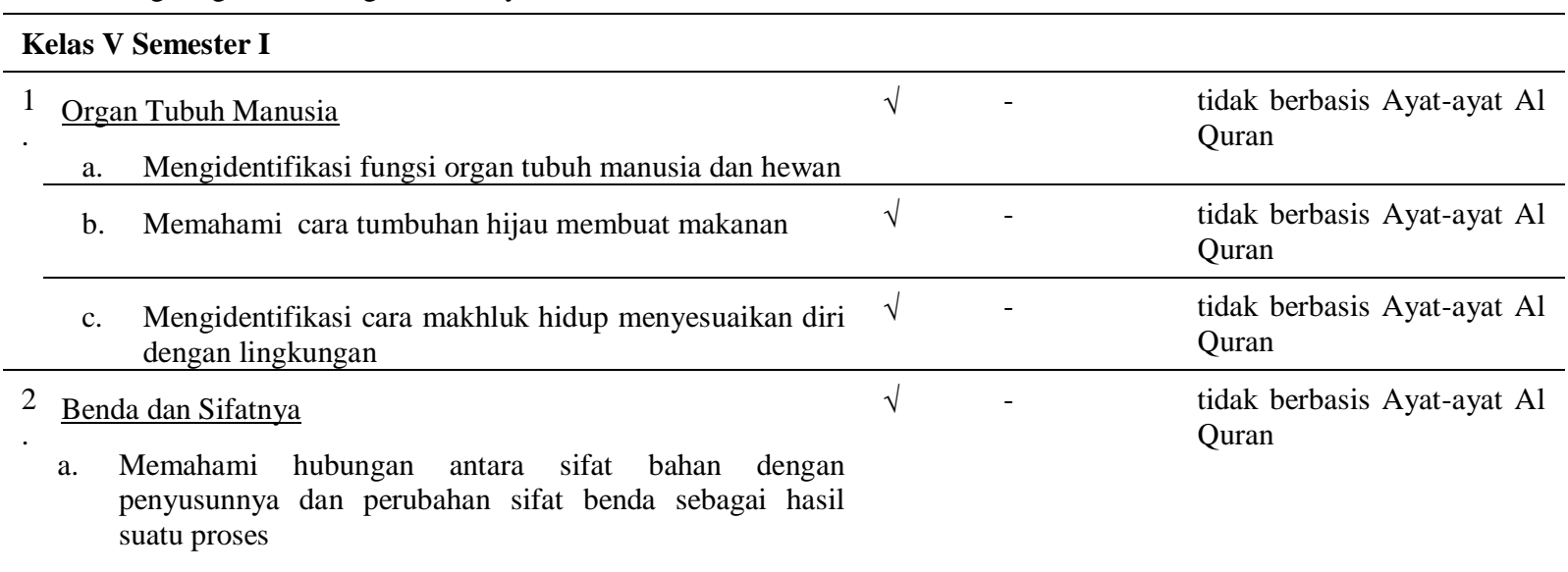

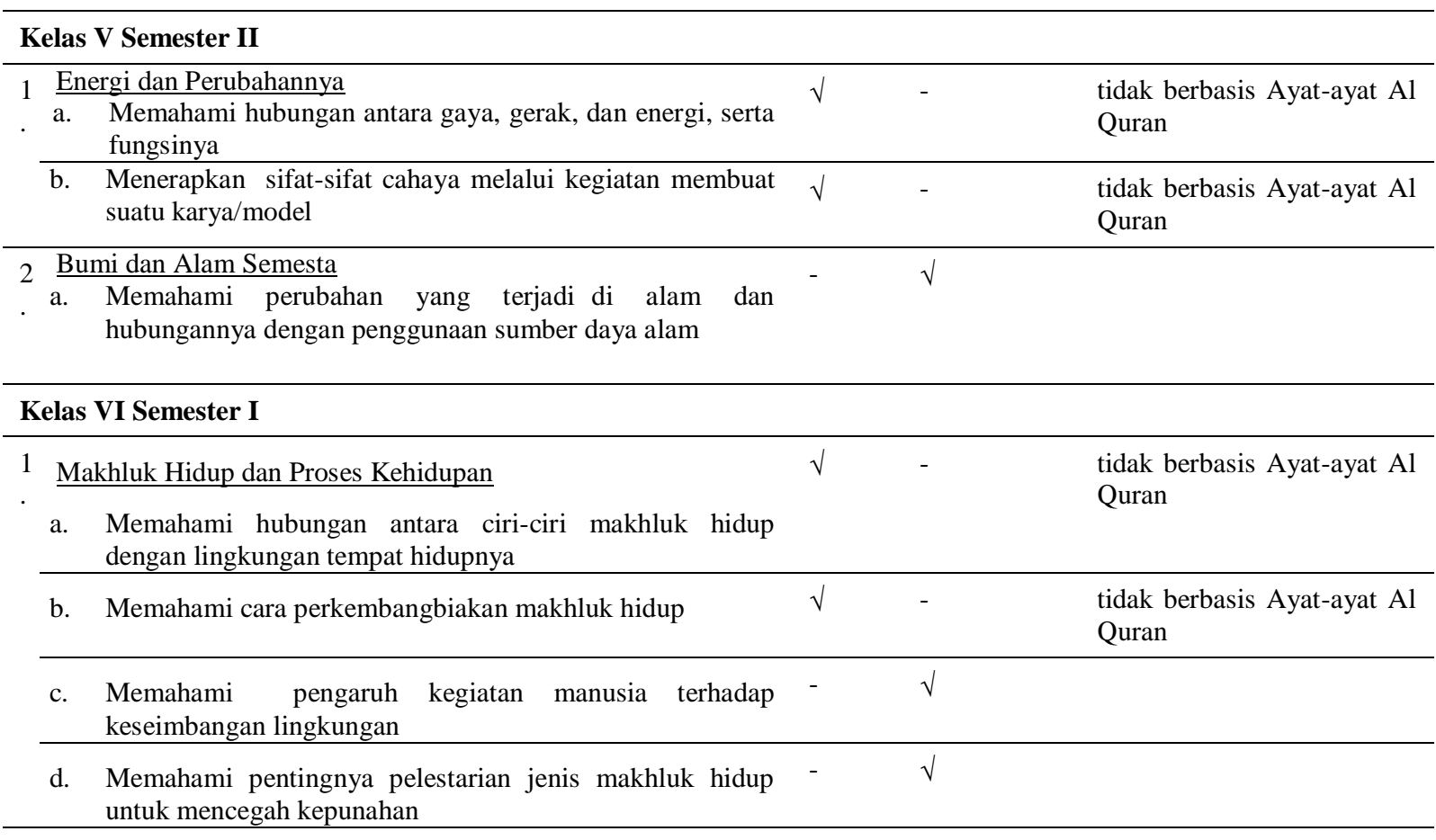




\begin{tabular}{|c|c|c|c|c|}
\hline \multirow{2}{*}{$\begin{array}{l}\mathbf{N} \\
\mathbf{0}\end{array}$} & \multirow{2}{*}{ Standar Kompetensi/Kompetensi Dasar } & \multicolumn{2}{|c|}{ Pedoman Praktikum } & \multirow[t]{2}{*}{ Keterangan } \\
\hline & & Ada & Tidak Ada & \\
\hline & $\underline{\text { Benda dan Sifatnya }}$ & $\sqrt{ }$ & - & $\begin{array}{l}\text { tidak berbasis Ayat-ayat } \mathrm{Al} \\
\text { Quran }\end{array}$ \\
\hline & $\begin{array}{l}\text { a. Memahami saling hubungan antara suhu, sifat hantaran } \\
\text { dan kegunaan benda }\end{array}$ & & & \\
\hline & b. & $\sqrt{ }$ & - & $\begin{array}{l}\text { tidak berbasis Ayat-ayat Al } \\
\text { Quran }\end{array}$ \\
\hline \multicolumn{5}{|c|}{ Kelas VI Semester II } \\
\hline \multirow{2}{*}{\multicolumn{2}{|c|}{$\begin{array}{l}1 \text { Energi dan Perubahannya } \\
. \text { a. Memahami pentingnya penghematan energi }\end{array}$}} & - & $\sqrt{ }$ & \\
\hline & & & & \\
\hline & $\begin{array}{l}\text { b. Memahami matahari sebagai pusat tata surya dan interaksi } \\
\text { bumi dalam tata surya }\end{array}$ & - & $\sqrt{ }$ & \\
\hline & Jumlah & 15 & 12 & \\
\hline & Persentasi & $56 \%$ & $44 \%$ & \\
\hline
\end{tabular}

Berdasarkan hasil observasi yang disajikan pada tabel 1 diketahui bahwa terdapat 27 materi pokok mata pelajaran IPA tingkat SD. Pedoman praktikum yang tersedia adalah $56 \%$ dari keseluruhan topik yang diajarkan. Seluruh pedoman praktikum tidak ditemukan pedoman yang berbasis ayat-ayat Al Quran.

Pedoman praktikum yang ditemukan memiliki karakteristik menggunakan instruksi langsung. Hofstein \& Lunetta (2004: 47) mengungkapkan bahwa sebagian besar prosedur praktikum diberikan kepada siswa dalam bentuk cook book. Hal ini menyebabkan siswa tidak berpikir tentang tujuan yang lebih besar dari apa yang siswa lakukan dan dari urutan-urutan yang langkah yang siswa butuhkan untuk mencapai tujuan-tujuan tertentu. Begitu pun dengan Millar (2004:17) yang mengungkapkan bahwa prosedur praktikum dalam bentuk cook book tidak mengarahkan siswa pada proses belajar, karena siswa tidak mengetahui apa dan mengapa melakukan langkah yang diperintahkan.

Kebutuhan pedoman praktikum IPA dapat mengakomodasi hakikat IPA sebagai suatu produk berupa fakta, proses sebagai pemecahan masalah, aplikasi kerja ilmiah dalam kehidupan sehari-hari dan sikap yang akan terwujud dari rasa ingin tahu tentang objek. Hal ini selaras dengan tujuan kurikulum IPA dimana pembelajaran IPA bertujuan untuk memberikan suatu fakta, konsep, maupun suatu proses penemuan. Sehingga pendidikan IPA dapat menjadi wahana bagi siswa untuk mempelajari dirisendiri dan alam sekitar. Hal ini tercermin pula pada kurikulum 2013 yang menekankan pada fenomena alam dan penerapannya dalam kehidupan sehari-hari. 


\section{B. Pengembangan Pedoman Praktikum Berbasis Al Quran Tema Tumbuhan}

Pengembangan pedoman praktikum dilakukan berdasarkan hasil analisis kelemahan dan kelebihan pedoman praktikum IPA di sekolah. Tahap pengembangan pedoman praktikum meliputi tahap pengembangan desain dan optimasi praktikum dan penyusunan buku pedoman praktikum siswa hingga dilakukan uji coba terbatas. Setelah proses tersebut, dilakukan penilaian karakteristik aspek pedagogi, konten, teknis dan estetik pedoman praktikum oleh ahli.

1. Pengembangan dan optimasi desain praktikum

Setelah desain praktikum disusun, dilakukan optimasi pada bahan praktikum yang bertujuan untuk melihat percobaan yang efektif dan efisien serta keajegan hasil percobaan sehingga di dapatkan praktikum yang optimal. Percobaan yang dilakukan pada setiap optimasi variabel sebanyak tiga kali. Penjabaran proses pengembangan dan optimasi desain praktikum adalah sebagai berikut.

a) Desain dan optimalisasi aktivitas mengelompokan tumbuhan

Desain kegiatan mengelompokan tumbuhan dikembangkan melalui pengelompokan tumbuhan darat dan tumbuhan air, kemudian tumbuhan dikotil dan monokotil. Dari desain ini siswa dapat menentukan jenis tumbuhan darat dataukah air suatu tumbuhan berdasarkan ciri-ciri yang dimiliki. Selain itu pada desain ini siswa dapat membedakan kelompok tumbuhan monokotil atau dikotil berdasarkan ciri tulang daun tumbuhan tersebut. Aktivitas yang dilakukan siswa adalah mengamati, menggambar dan mengelompokan jenis tumbuhan.

Untuk mengembangkan aktivitas ini, pada aspek teknis dilakukan pemilihan gambar dan jenis kegiatan yang dilakukan. Pemilihan gambar yang menunjukan tumbuhan darat dan air yang representatif. Kegiatan yang dilakukan adalah mengamati tumbuhan di sekitar lingkungannya, lalu mengamati daun sebagai petunjuk pengelompokan. Pemilihan organ daun berdasar pada mudahnya mengamati daun dari pada bunga, batang dan akar sebagai dasar klasifikasi. Bunga, tidak semua tumbuhan ditemukan pada keadaan berbunga. Batang, pengamatan batang secara spesifik harus menggunakan mikroskop. Akar, siswa akan menemukan kesulitan mengamati akar pohon yang besar. Oleh karena itu, daun merupakan pilihan terbaik sebagai objek pengelompokan tumbuhan.

2. Pengembangan buku pedoman praktikum siswa

Pedoman praktikum yang dikembangkan tersusun dari tiga aktivitas, meliputi (1) mengelompokan tumbuhan; (2) pertumbuhan dan perkembangan tumbuhan; dan (3) 
perkembangbiakan tumbuhan. Dalam proses pengembangannya, dilakukan strategi pengembangan yang telah dijabarkan pada kajian pustaka. Aktivitas dikembangkan melalui pendekatan inkuiri dengan metode saintifik tipe 5M (Menanya, Mengamati, Mencoba, Menalar dan Mengkomunikasikan). Secara lengkap pedoman praktikum terlampir pada Lampiran A. Langkah pembelajaran melalui praktikum secara umum, mencakup:

a) Tujuan praktikum

Judul praktikum dibuat singkat, jelas menggambarkan praktikum yang akan dilakukan oleh siswa dan komunikatif bagi siswa. Judul Praktikum yang dikembangkan melalui tema tumbuhan dalam penelitian ini terdiri dari tiga kegiatan yaitu (1) mengelompokan tumbuhan; (2) pertumbuhan dan perkembangan tumbuhan; dan (3) perkembangbiakan tumbuhan.

b) Fenomena

Fenomena merupakan gambaran dari suatu situasi atau permasalahan dan disarankan situasi atau permasalahan tersebut terjadi dalam kehidupan sehari-hari. Hal ini bertujuan agar siswa lebih mudah menelaah permasalahan yang dihadirkan dalam kegiatan praktikum. Fenomena yang disajikan dalam praktikum mengelompokan tumbuhan yang dikembangkan berupa beragamnya tumbuhan yang hidup di taman, baik tumbuhan air maupun darat. Fenomena yang disajikan dalam praktikum perkembangan dan pertumbuhan adalah gambaran pertumbuhan biji menuju perkecambahan yang memiliki beragam ukuran. Fenomena yang disajikan untuk kegiatan perkembangbiakan tumbuhan adalah gambar berbagai agen penyerbukan, seperti lebah, angin, dan kupu-kupu.

c) Arahan dalam Mengamati

Berisi arahan mengamati suatu objek pada buku pedoman maupun lingkungan sekitar. Pertanyaan pengarah yang disusun seperti: Amatilah gambar di bawah ini, temukanlah jenis tumbuhan air dan tumbuhan darat pada gambar tersebut.

d) Arahan dalam Mengumpulkan Data dan Mengelompkan

Arahan dalam mengumpulkan data dimulai dari arahan mendesain percobaan dan menyajikan data. Arahan untuk menyajikan data dilakukan melalui pertanyaan dan disediakan kolom untuk siswa membuat tabel dengan menentukan variabelnya masing-masing. 
e) Arahan membuat kesimpulan

Siswa diminta untuk menuliskan kesimpulan hasil percobaannya. Pertanyaan arahan disusun seperti: Apa kesimpulan dari hasil percobaanmu?

Pada awal kegiatan siswa diberikan pendahuluan berupa ayat yang berhubungan dengan materi yang akan dipelajari. Adapun contoh lembar kerjanya adalah sebagaimana gambar 2 berikut:

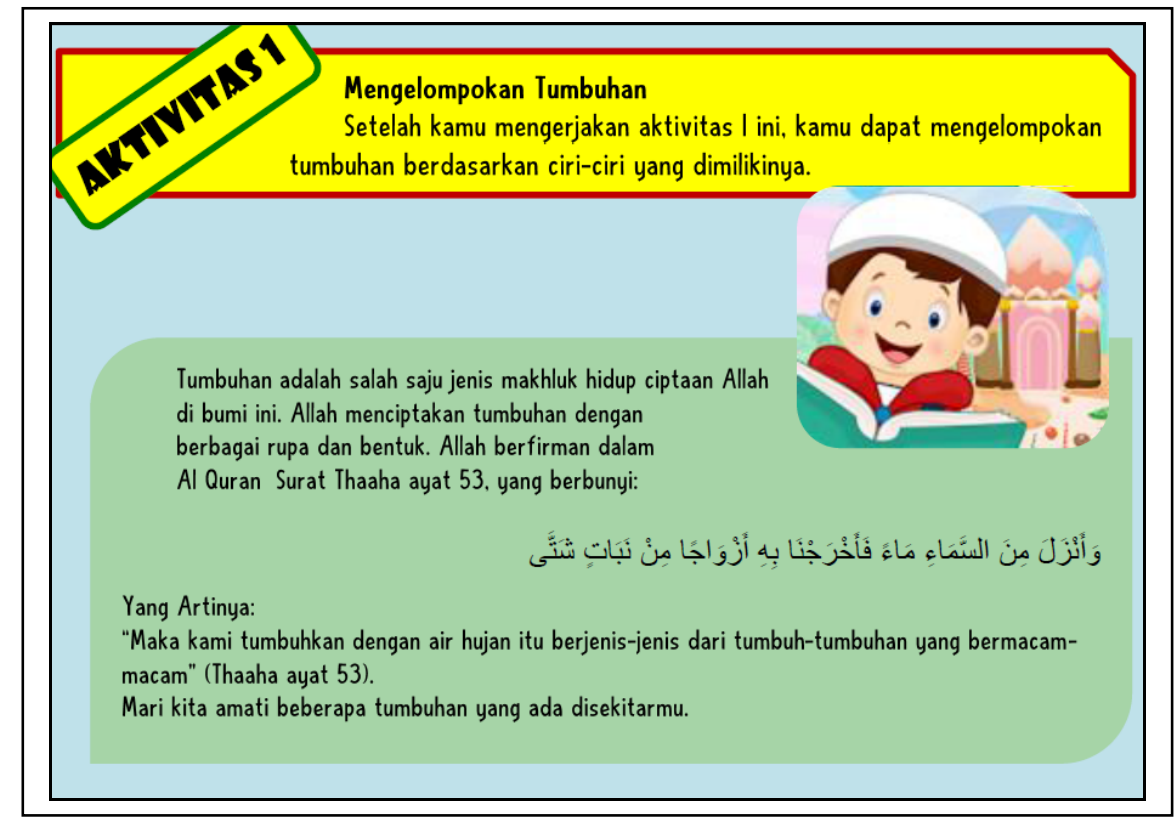

Gambar 2. Ayat Al Quran Dalam Proses Pembelajaran

Kegiatan selanjutnya siswa mengelompokan berdasarkan pengamatan terhadap gambar. Keterampilan proses yang dikembangkan adalah mengamati dan mengelompokan.

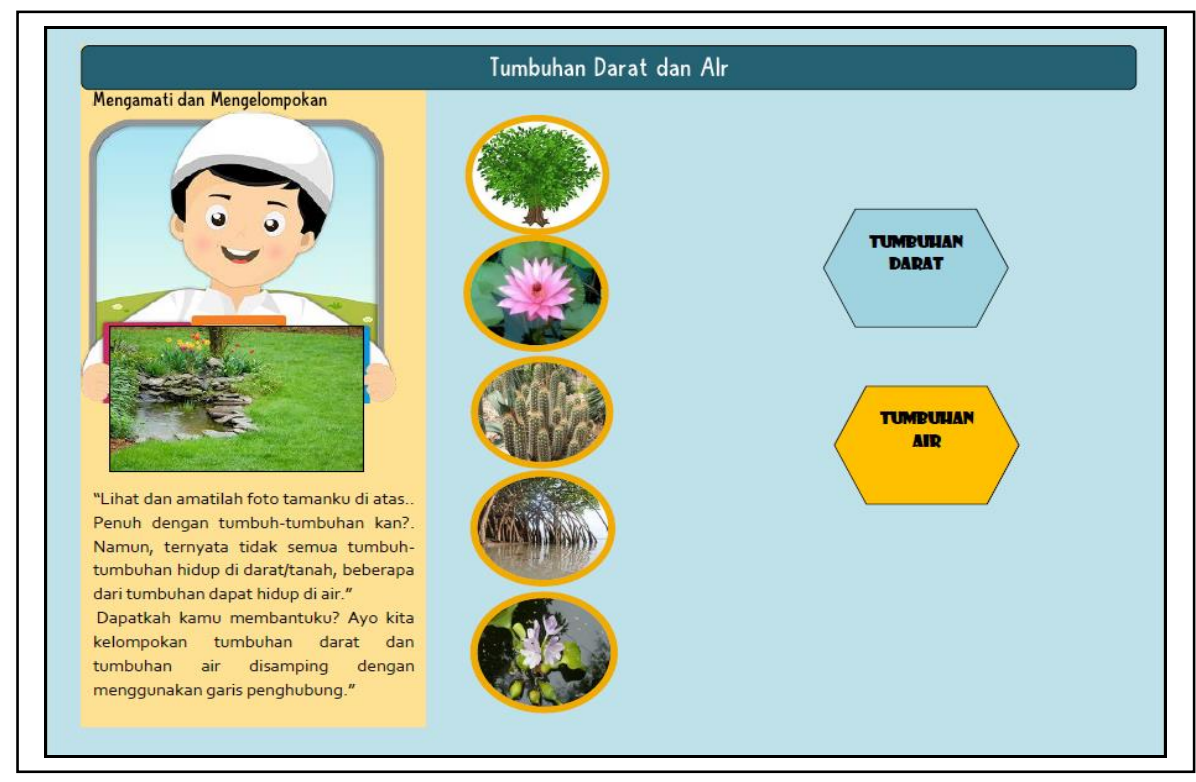

Gambar 3. Cuplikan kegiatan mengamati dan mengelompokan 
Kegiatan yang dapat ditemukan dalam pedoman yang dikembangkan adalah kegiatan percobaan langsung perkecambahan. Keterampilan proses yang dikembangkan adalah mengamati, mengukur, mengomunikasi, menganalisis dan menyimpulkan.

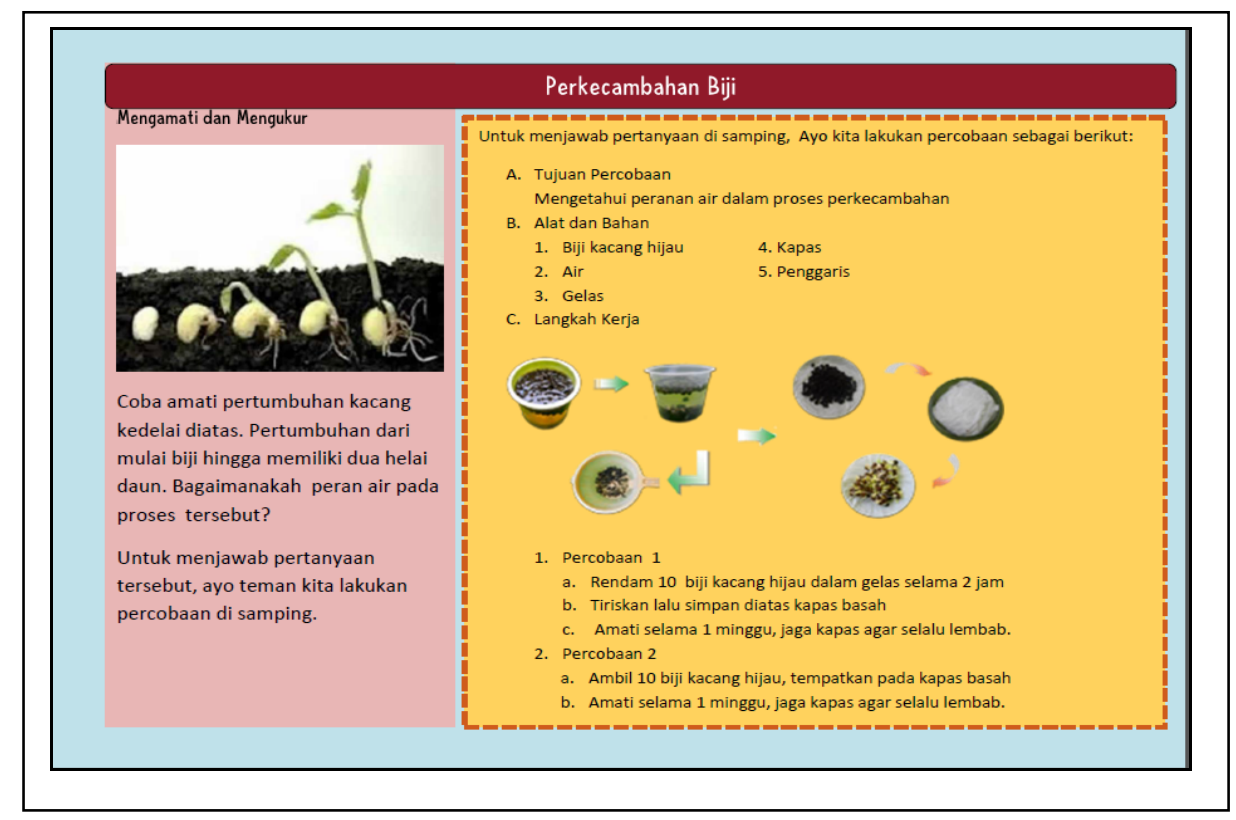

Gambar 4. Cuplikan kegiatan percobaan perkecambahan

\section{Uji Coba Terbatas}

Uji coba dilakukan bertujuan untuk mengetahui nilai efektifitas prosedur dan keajegan siswa dalam mengerjakan praktikum. Responden uji coba terbatas adalah lima orang siswa SD/MI dan 10 orang mahasiswa Sarjana Pendidikan Guru Madrasah Ibtidaiyah. Seluruh kegiatan siswa di observasi selama kegiatan praktikum. Data dikumpulkan melalui lembar uji coba setiap praktikum dan observasi.

Untuk mengetahui nilai efektifitas prosedur praktikum, dilakukan dengan cara responden memberikan poin 1 (satu) jika langkah dapat dilakukan tanpa kendala dan 0 (nol) jika langkah tidak berhasil atau menemui kendala. Nilai tersebut kemudian dipresentasekan dan dikategorikan berdasarkan rentang yang telah ditentukan pada Nilai efektifitas pada setiap praktikum disajikan pada Tabel 2 berikut.

Tabel 2. Nilai keberhasilan mengikuti instruksi langkah kerja

\begin{tabular}{|c|c|c|c|c|c|c|c|}
\hline \multirow[t]{2}{*}{ No } & \multirow[t]{2}{*}{ Aktivitas } & \multicolumn{4}{|c|}{$\begin{array}{l}\text { Nilai Keberhasilan Mengikuti } \\
\text { Instruksi Langkah Kerja }\end{array}$} & \multirow{2}{*}{$\begin{array}{l}\text { Nilai } \\
\text { Efektifitas }\end{array}$} & \multirow[t]{2}{*}{ Kategori } \\
\hline & & $\begin{array}{ll} & 2\end{array}$ & 3 & 4 & 5 & & \\
\hline 1 & $\begin{array}{l}\text { Mengelompokan } \\
\text { Tumbuhan }\end{array}$ & 1 & & & & $100 \%$ & Sangat Baik \\
\hline 2 & $\begin{array}{l}\text { Pertumbuhan dan } \\
\text { Perkembangan }\end{array}$ & 1 & 0 & 1 & 1 & $80 \%$ & Sangat Baik \\
\hline 3 & Perkembangbiakan & $1 \quad 1$ & 1 & 1 & & $100 \%$ & Sangat Baik \\
\hline \multicolumn{6}{|c|}{ Rata-rata persentase efektifitas praktikum } & $93,3 \%$ & Sangat Baik \\
\hline
\end{tabular}


Berdasarkan data pada Tabel 2 terlihat bahwa Aktivitas I dan III mencapai nilai 100\% efektif. Sedangkan ditemukan praktikum II mencapai $80 \%$. Kelemahan pada desain produk awal praktikum II ini adalah tidak memberikan gambar petunjuk langkah kerja. Rata-rata persentase efektifitas menunjukkan nilai sangat baik $(93,3 \%)$.

\section{Karakteristik Pedoman Praktikum Berdasarkan Aspek Pedagogi, Konten, Teknis dan Estetika}

Penilaian karakteristik pedoman praktikum dilakukan untuk mendapatkan gambaran kekuatan dari pedoman praktikum yang dikembangkan pada aspek pedagogi, konten, teknis dan estetik. Pengembangan komponen pedoman dilakukan dengan berlandaskan pada keempat aspek tersebut. Pada proses pengembangannya, aspek pedagogi, konten, teknis dan estetik diupayakan selalu hadir dalam setiap komponen pedoman. Pada Tabel 3 dijabarkan kemunculan aspek tersebut dalam pedoman yang dikembangkan.

Tabel 3. Penjabaran Aspek Pedagogi, Konten, Teknis dan Estetik pada setiap Komponen Pedoman Praktikum Sains

\begin{tabular}{|c|c|c|c|c|}
\hline \multirow{2}{*}{ Komponen } & \multicolumn{4}{|l|}{ Aspek } \\
\hline & Pedagogi & Konten & Teknis & Estetik \\
\hline $\begin{array}{l}\text { Pedoman } \\
\text { Praktikum }\end{array}$ & $\begin{array}{l}\text { Pedoman praktikum } \\
\text { disusun berdasarkan } \\
\text { dengan pendekatan KPS } \\
\text { dan metode saintifik. } \\
\text { Bahasa pengantar } \\
\text { interaktif dan tidak terlalu } \\
\text { baku, agar mudah } \\
\text { dipahami siswa, sesuai } \\
\text { dengan tingkat intelektual } \\
\text { siswa SD/MI. }\end{array}$ & $\begin{array}{l}\text { Pedoman praktikum } \\
\text { memuat informasi dan } \\
\text { ilustrasi yang tepat sesuai } \\
\text { tema pembelajaran. }\end{array}$ & $\begin{array}{l}\text { Buku Aktivitas Siswa } \\
\text { didesain dalam bentuk buku } \\
\text { ukuran B5. Sehingga mudah } \\
\text { dikemas dan digunakan. }\end{array}$ & $\begin{array}{l}\text { Buku Aktivitas } \\
\text { Siswa didesain } \\
\text { menggunakan } \\
\text { warna pastel yang } \\
\text { bersifat ceria, } \\
\text { sesuai dengan usia } \\
\text { siswar } \\
\text { Dilengkapi gambar } \\
\text { animasi yang } \\
\text { menarik bagi } \\
\text { siswa. }\end{array}$ \\
\hline $\begin{array}{l}\text { Kesesuaian } \\
\text { penerapan } \\
\text { Ayat Al } \\
\text { Quran }\end{array}$ & $\begin{array}{l}\text { Ayat Al Quran yang } \\
\text { dipilih diharapkan } \\
\text { mampu menambah } \\
\text { motivasi siswa untuk } \\
\text { membaca Al Quran } \\
\end{array}$ & $\begin{array}{l}\text { Ayat Al Quran yang dipilih } \\
\text { merupakan ayat yang } \\
\text { sesuai tema pembelajaran }\end{array}$ & $\begin{array}{l}\text { Ayat Al Quran yang dipilih } \\
\text { merupakan ayat pendek yang } \\
\text { sesuai tema pembelajaran }\end{array}$ & \\
\hline $\begin{array}{l}\text { Alat yang } \\
\text { digunakan }\end{array}$ & - & - & $\begin{array}{l}\text { Alat yang digunakan dipilih } \\
\text { dari kemudahan } \\
\text { penggunaannya. Seperti gelas } \\
\text { dan kapas }\end{array}$ & \\
\hline $\begin{array}{l}\text { Bahan } \\
\text { yang } \\
\text { digunakna }\end{array}$ & $\begin{array}{l}\text { Bahan praktukum berasal } \\
\text { dari lingkungan siswa } \\
\text { sehari-hari, sehingga } \\
\text { bersifat kontekstual. }\end{array}$ & - & $\begin{array}{l}\text { Bahan dioptimasi untuk } \\
\text { mendapatkan hasil yang } \\
\text { akurat. } \\
\text { Bahan tidak berbahaya bagi } \\
\text { siswa. }\end{array}$ & \\
\hline
\end{tabular}

Untuk mendapatkan penilaian terhadap produk yang dikembangkan berdasarkan aspek pedagogi, konten, teknis dan estetik, dilakukan judgment oleh ahli. Responden yang melakukan judgment adalah dua orang Dosen sejawat. Instrumen yang digunakan merupakan rating scale yang memuat 12 pertanyaan dengan skala 0-4. Hasil penilaian ahli dalam judgment expert di konversi dalam bentuk persentase. Data presentase dikategorikan menjadi sangat kuat, kuat, 
cukup, lemah dan sangat lemah sesuai pencapaiannya. Persentase penilaian pedoman praktikum dijabarkan pada Tabel 4 berikut.

Tabel 4. Persentase karakteristik pedoman praktikum berdasarkan aspek pedagogi, konten, teknis, dan estetik

\begin{tabular}{|c|c|c|c|c|c|c|}
\hline Aspek & Indikator & $\begin{array}{l}\text { Rata-rata } \\
\text { penilaian ahli } \\
(0-4)\end{array}$ & $\begin{array}{l}\text { Persentase } \\
\text { penilaian } \\
(1-100 \%)\end{array}$ & Kriteria & $\begin{array}{l}\text { Rata- } \\
\text { rata per- } \\
\text { aspek }\end{array}$ & Kriteria \\
\hline \multirow[t]{2}{*}{ Pedagogi } & $\begin{array}{l}\text { 1. Standar proses dalam } \\
\text { pedoman selaras dengan } \\
\text { tuntutan kurikulum }\end{array}$ & 3.50 & 87.50 & Sangat kuat & \multirow[t]{2}{*}{87.5} & \multirow[t]{2}{*}{ Sangat kuat } \\
\hline & $\begin{array}{l}\text { 2. Aktivitas sesuai dengan } \\
\text { tingkat intelektual siswa }\end{array}$ & 3.50 & 87.50 & Sangat kuat & & \\
\hline \multirow[t]{5}{*}{ Konten } & $\begin{array}{l}\text { 3. Konten sesuai dengan standar } \\
\text { isi }\end{array}$ & 3.25 & 81.25 & Sangat kuat & \multirow{5}{*}{86.25} & \multirow{5}{*}{ Sangat kuat } \\
\hline & 4. Kesesuaian ayat & 3.75 & 93.75 & Sangat kuat & & \\
\hline & $\begin{array}{l}\text { 5. Praktikum sesuai dengan } \\
\text { tujuan pembelajaran }\end{array}$ & 3.75 & 93.75 & Sangat kuat & & \\
\hline & 6. Ketepatan informasi & 3.25 & 81.25 & Sangat kuat & & \\
\hline & 7. Ketepatan ilustrasi & 3.25 & 81.25 & Sangat kuat & & \\
\hline \multirow[t]{3}{*}{ Teknis } & 8. Kemudahan penggunaan & 3.00 & 75.00 & Kuat & \multirow{3}{*}{81,25} & \multirow{3}{*}{ Kuat } \\
\hline & $\begin{array}{l}\text { 9. Alat dan bahan yang tidak } \\
\text { berbahaya }\end{array}$ & 3.50 & 87.50 & Sangat kuat & & \\
\hline & 10. Akurasi & 3.25 & 81.25 & Sangat kuat & & \\
\hline \multirow[t]{2}{*}{ Estetik } & 11. Komposisi warna & 3.50 & 87.50 & Sangat kuat & \multirow{2}{*}{87.5} & \multirow{2}{*}{ Sangat kuat } \\
\hline & 12. Keterbacaan & 3.50 & 87.50 & Sangat kuat & & \\
\hline Rata-rata & & 3.35 & 83.85 & Sangat kuat & 85,6 & Sangat kuat \\
\hline
\end{tabular}

Berdasarkan data pada Tabel 4 diketahui bahwa nilai tertinggi dicapai oleh aspek konten dengan indikator praktikum sesuai tujuan pembelajaran $(93,75 \%)$ dan kesesuaian ayat dengan konten $(93,75 \%)$. Sedangkan nilai terendah adalah pada aspek teknis pada indikator kemudahan penggunaan (75\%). Secara keseluruhan pedoman praktikum memiliki kriteria pedoman praktikum yang sangat kuat $(85,6 \%)$ pada semua aspek.

\section{SIMPULAN}

Berdasarkan analisis data dan pembahasan yang telah dilakukan terhadap hasil penelitian, dapat ditarik kesimpulan sebagai berikut:

1. Keberadaan pedoman aktivitas praktikum siswa dalam menunjang pembelajaran SD adalah 54\% dari 27 topik IPA pada Kompetensi Dasar. Tidak ditemukan pedoman praktikum yang berbasis ayat Al Quran.

2. Pedoman Praktikum sains berbasis Al Quran telah melalui tahap pengembangan meliputi proses optimasi bahan, pemilihan alat serta waktu reaksi. Setelah melalui serangkaian uji coba dan perbaikan desain, kemudian dilakukan tahap penilaian dan identifikasi karakteristik pedoman praktikum. Hasil penilaian karakteristik produk menunjukkan bahwa pedoman praktikum sains berbasis Al Quran mengandung aspek pedagogi (87.5\%), konten (86.25\%), 
teknis $(81.25 \%)$ dan estetik $(87.5 \%)$ yang ditafsirkan memiliki kriteria pedoman praktikum yang sangat baik.

\section{DAFTAR PUSTAKA}

Al-Qur'an dan terjemahannya. 2008. Departemen Agama RI. Bandung: Diponegoro.

Borg, W. R dan Gall, M.D. 2003. Education Research: An introduction. New York: Longman, Inc.

Hofstein, A. dan Lunnetta. 2002. The Laboratoty in Science Education:Foundationt for twentyFirst Century. Wiley Periodical, 2003,29-54.

Hofstein, A. dan Mamlock, N. R. 2007. The laboratory in Science Education: the State of the Art, Chemistry Education Research and Practice, 2007,8 (2), 105-107.

Jasin, M. 2008. Ilmu Alamiah Dasar. Jakarta: PT Raja Grafindo Persada.

Millar, R. 2004. The role of practical work in the teaching and learning of science. Washington, DC. National Academic of Science.

Murtono . 2005. Pendidikan Sians dalam Al-Quran. Jurnal Pendidikan Agama Islam Vol 2 No. 2.

Rustaman, N. 2003. Strategi Belajar Mengajar Biologi. Bandung: Jurusan Pendidikan Biologi: FPMIPA UPI

Sanjaya, H. W. 2009. Strategi Pembelajaran Berorentasi Standar Proses Pendidikan. Jakarta: Kencana

Supriatno, B. 2013. Pengembangan Program Perkuliahan Pengembangan Praktikum Biologi Sekolah Berbasis ANCORB untuk Mengembangkan Kemampuan Merancang dan Mengembangkan Desain Kegiatan Laboratorium. (Disertasi). Sekolah Pascasarjana, Universitas Pendidikan Indonesia.

Winataputra, U.S. 1993. Materi Pokok Strategi Belajar Mengajar IPA. Jakarta: Depdikbud 